and special arrangements are planned for educationists and writers of school and university text-books. British books cannot, however, be purchased by Germans. The Control Commission has officially approved a scheme, put forward by the Agency for Intellectual Relief in Germany, under which the Agency will establish lending libraries for British books in key-centres of the British zone. The first library, containing some four thousand books, is being opened in Hamburg. Once the libraries have been established, German committees in each town will take over the management; it is expected that current expenditure in Germany will be covered by the borrowers' fees. A list of books needed, based on suggestions by German readers, has been prepared. Contributions are solicited towards the cost of books that must be bought; cheques should be sent to the honorary treasurer of the Agency for Intellectual Relief in Germany, C. P. Kininmonth, 4 Chapel Row, Wheeler End, High Wycombe, Bucks. Information relating to the scheme can be obtained from the Agency for Intellectual Relief in Germany, Foreign Office, German Section, 48 Prince's Gardens, London, S.W.7.

\section{Import of Scientific and Technical Books}

Replying to a question in the House of Commons, the President of the Board of Trade stated that he is prepared to consider the issue of licences for limited additional imports of technical and scientific books in English from certain European countries. Similar books in foreign languages from non-English speaking countries are licensed freely.

\section{German Hydrographic Institute, Hamburg}

Tre first annual report of the German Hydrographic Institute, Hamburg, consists of a 64-page booklet both in German and English (the former language being that of the official text). It gives a good account of the provision which has been made in Germany since the War for the performance of the various tasks formerly undertaken by the organisation which was the German analogue of the Hydrographic Department of the British Admiralty. Along with that account, which tells of work to do with marine surveying, the making and printing of nautical charts, the issue of nautical books, the testing of compasses, the observation and publication of magnetic values, the issue of time signals, and with many other matters concerning which information is needed by mariners and required by the naval side of the Allied occupying authority, there is substantial information bearing upon the present state of German oceanography.

Before the War, the science of oceanography had numerous practitioners in Germany, and, in addition to the two well-known and very large organisations devoted to its furtherance, there were several small scientific bodies of repute which worked in this sphere. The report records how plans were laid for the em. ployment of about one-fifth of the large number of oceanographers to work upon tasks which should serve the interests of, and meet the needs of, that rump organisation which-it was approved by the Allied Control Council-had to be set up to carry out essential hydrographical duties in German waters. These scientific workers ultimately became Section 2 of the Institute which is the subject of the report. This, established initially by the British naval authorities, is now under the governance of a quadripartite board of four directors, functions in Hamburg, and is 'managed' by the British director, who is a captain in the Royal Navy. Considerable information is given concerning reports which have been written by various German marine scientific workers since the capitulation, and it is expected soon to start upon the issue of a periodical wherein such reports will be printed for circulation.

\section{National Foundry College}

THe National Foundry College has been established and its board of governors nominated by the Minister of Education. The College will be housed in, and work closely in conjunction with, the Wolverhampton and Staffordshire Technical College. The board of governors is eharged with the responsibility for providing national facilities for foundry education and research, in the form of full-time courses, vacation courses, refresher courses, and the like, and also for providing regional and local facilities for full-time, part-time day and evening courses, to cover the whole range of foundry education. Its first task will be the re-establishment of the full-time diploma course which was the main feature of the predecessor of the College, the British Foundry School, during 1935-39. This course will normally run for an academic year, and the first session opens on January 5. The course will cover the whole of the foundry industry, ferrous and non-ferrous, including grey, white and chilled iron castings, malleable castings, steel castings, and castings in non-ferrous metals, such as alloys of copper, tin, zine, nickel, aluminium and magnesium. The diploma awarded to successful students will be endorsed by the Ministry of Educa. tion. There is no upper age limit for admission; a minimum of one year's practical experience in at least one branch of the industry will be required, together with a Higher National Certificate or a university degree, preferably in metallurgy or engineering, or a grade of membership obtained by examination of a professional institution in engineering, metallurgy or chemistry. Mr. J. Bamford, who was in charge of the British Foundry School during 1935-39, and who has since held important managerial appointments in the industry, has been appointed head of the National Foundry College.

\section{Abstracts on Powder Metallurgy}

Hrthento available in private circulation only, Metal Powder Report is now issued at an annual subscription of $£ 37 s .6 d$. The report is a sixteen-page monthly abstract journal dealing solely with the production, treatment and use of metal powders, under the joint editorship of W. D. Jones and R. A. Hetzig. The use of such products in electronics, the metallization of glass and ceramic materials, iron driving bands, porous aluminium-base bearings, electrical contacts, magnetic materials, sintered plates for batteries, sparking plugs, and stainless steel powders for paints and lacquers, all of which are mentioned in the issues for September and October 1947, will give an indication of the surprising breadth of interest of this very new branch of metallurgy. All concerned with powder metallurgy in any of its aspects will find this publication of real use. It is available from Powder Metallurgy, Ltd., Commonwealth House, 1-19 New Oxford Street, London, W.C.1.

\section{Biological Abstracts}

A NEW section of Biological Abstracts (University of Pennsylvania, Philadelphia) will be published as from January 1948. The section ( $J$-Abstracts of 